\title{
Tussen creatief en compliant
}

\section{De mate waarin gemeentecontrollers de BBV-bepalingen naleven}

\author{
Rick Anderson
}

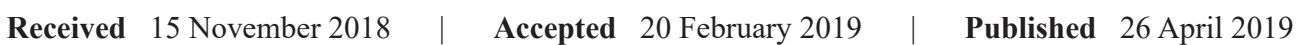

\section{Samenvatting}

Controllers worden soms geconfronteerd met verzoeken van managers die zich niet altijd goed verhouden tot de wettelijke bepalingen. De vraag rijst dan hoe controllers hiermee omgaan. Deze bijdrage doet verslag van een onderzoek dat is uitgevoerd naar de manier waarop controllers binnen gemeenten omgaan met een mogelijke spanning die kan bestaan tussen enerzijds verzoeken van managers en anderzijds wettelijke voorschriften. Hiertoe zijn controllers en ambtenaren van 22 gemeenten geënquêteerd. Het blijkt, dat het merendeel van de controllers bewust afwijkt van sommige voorschriften. Daarbij speelt de inschatting van de gevolgen van compliance of juist non-compliance een rol, alsmede de positionering van de controller binnen de gemeente.

\section{Relevantie voor de praktijk}

Hoewel gemeentecontrollers over het algemeen goed op de hoogte zijn van de voorschriften die gehanteerd moeten worden bij het voeren van de financiële administratie, kan niet gesteld worden dat iedere controller zich aan die voorschriften houdt. Dit onderzoek levert enkele verklaringen aan voor de mate waarin controllers deze voorschriften naleven.

\section{Trefwoorden}

Public controlling, compliance, naleving

\section{Inleiding}

Controllers binnen Nederlandse gemeenten worden doorgaans met verschillende wensen en verzoeken van managers en budgethouders geconfronteerd (Aardema 2000; Strikwerda 2002). Deze wensen en verzoeken kunnen van zeer uiteenlopende aard zijn, maar zijn doorgaans wel terug te leiden tot de belangen van deze managers en budgethouders (Anderson 2006). Naarmate deze belangen verder uiteenlopen, ontstaat een navenante verscheidenheid en soms spanning tussen de verschillende wensen en vragen die gesteld worden aan een gemeentelijke controller (Otley 1994; Van Helden 1998). Hier zal de gemeentecontroller een balans moeten zien te vinden. Een controller met een te facilitaire grondhouding loopt het risico dat de gemeente "uit control" raakt. Controllers die daarentegen de balans laten uitslaan richting controle en toezicht, raken uitein- delijk verstoken van informatie, een basisbehoefte van de gemeentecontroller (Fenger 2001; Vosselman 2005).

Naast bovenbeschreven spanning kan zich tevens een andere spanning voordoen bij de werkzaamheden van de gemeentecontroller: d.w.z. de spanning die kan bestaan tussen de wensen van de gemeentelijke organisatie en datgene wat wettelijk is voorgeschreven (vgl. Merchant and Rockness 1994, p. 84). Hoewel dit in de praktijk niet dagelijks voorkomt, worden gemeentecontrollers soms geconfronteerd met wensen van managers die minder goed wettelijk zijn in te passen (Aardema 2007). Een vermeende spanning tussen doelmatigheid en conformiteit aan wettelijke bepalingen kan hieraan ten grondslag liggen (Price et al. 2016; Behn 2001; Mangia et al. 2013). Conformiteit aan wettelijke bepalingen (compliance, vgl. Pronk 2003) staat bij controllers van oudsher hoog in het vaandel, evenals het onderliggende waardepatroon dat hieraan ten 
grondslag ligt (Jansen 2008). Aan de andere kant wordt in toenemende mate duidelijk, dat ook wettelijke bepalingen hun beperkingen hebben waar het effectiviteit betreft en dat een hoge mate van compliance de doelmatigheid van werken niet altijd in de hand werkt (Hertogh and Weyers 2011; Gelderman et al. 2006; Price et al. 2016; Mangia et al. 2013). Als gevolg hiervan houdt niet iedereen zich in gelijke mate aan wettelijke bepalingen, soms onbewust, soms bewust (Huls 2015; Lin et al. 1993).

Hoewel vrij veelvuldig onderzoek is verricht naar de manier waarop veranderingen in financiële wettelijke bepalingen worden doorgevoerd binnen een organisatie (Robalo 2014; Burns and Scapens 2000; Carpenter and Feroz 2001), naar ethische vraagstukken gerelateerd aan resultaatbeïnvloeding (Merchant and Rockness 1994, p. 92; Kaplan 2001) en ook veelvuldig onderzoek voorhanden is naar integriteit onder ambtenaren (De Graaf and Strüwer 2014), is minder onderzoek uitgevoerd naar specifiek de mate van compliance bij gemeentelijke controllers of interne auditdiensten en de factoren die deze mate kunnen verklaren (Kidwell 1999; Lin et al. 1993). Uiteraard stellen accountants bij de controle van de gemeentelijke jaarstukken hun verslagen op, maar deze verslagen hebben betrekking op het gecontroleerde boekjaar van de desbetreffende gemeente. Een algemeen beeld wordt daarmee logischerwijs niet verkregen.

In dit onderzoek wordt bezien hoe gemeentecontrollers met de mogelijke spanning omgaan, die kan bestaan tussen de wensen van hun managers enerzijds en het naleven van wettelijke bepalingen anderzijds. Daarnaast beoogt dit onderzoek factoren te traceren die de afweging verklaren die gemeentecontrollers maken in hun beslissing al dan niet tot compliance over te gaan. Dit onderzoek gaat niet in op ethische aspecten: het niet naleven van wettelijke bepalingen kan een ethische rechtvaardiging hebben, terwijl het strikt naleven van bepalingen in sommige gevallen op ethische gronden aangevochten kan worden (Merchant and Rockness 1994, p. 82).

Ten behoeve van dit onderzoek is de volgende onderzoeksvraag geformuleerd:

In welke mate leven gemeentecontrollers de wettelijke bepalingen na, zoals geformuleerd in het BBV en welke factoren kunnen deze mate verklaren?

Eerst wordt ingegaan op de geselecteerde wettelijke bepaling en op verklaringen die de mate van compliance kunnen verklaren. Vervolgens wordt de conceptualisering, alsmede de opzet van het onderzoek uiteengezet. Het artikel vervolgt met een analyse van de resultaten en sluit af met enkele conclusies.

\section{Goed koopmansgebruilk voor de gemeentecontroller}

Het onderzoeksobject voor dit onderzoek is de mate waarin gemeentecontrollers de wettelijke bepalingen volgen in hun financiële administratie.
Hiertoe is één bepaling geselecteerd (vgl. Carpenter and Feroz 2001). Daarbij is van belang dat dit een bepaling is, die goed bekend is bij controllers, terwijl tevens uit eerdere ervaringen bekend is, dat zich spanning kan voordoen tussen deze bepaling en de wensen van gemeentelijke managers en/of budgethouders.

Een belangrijk wettelijk ankerpunt voor de gemeentelijke financiële administratie betreft het Besluit Begroting en Verantwoording (BBV). Het BBV is te zien als de tegenhanger van de regelgeving die leidend is voor de verslaglegging voor de private sector, te weten de bepalingen die zijn voorgeschreven voor de opstelling en vormgeving van de jaarrekening, zoals in eerste instantie neergelegd in het Burgerlijk Wetboek 2, Titel 9 en de Richtlijnen voor de Jaarverslaggeving (Commissie BBV 2017; Bordewijk and Klaassen 2011).

Artikel 2 lid 1 van het BBV schrijft het stelsel van baten en lasten voor (BBV 2018). Artikel 2 lid 2 van het BBV bepaalt dat de baten en de lasten in de jaarstukken worden opgenomen, onverschillig of zij tot inkomsten of uitgaven in dat jaar leiden, hetgeen als een uitwerking van het stelsel van baten en lasten kan worden opgevat. "In het stelsel van baten en lasten worden uitgaven en inkomsten toegerekend aan de jaren waarop de bijbehorende prestaties betrekking hebben (..). Het vereiste van toerekenen houdt in dat de gevolgen van transacties en andere gebeurtenissen in de administratie worden geboekt en in de jaarrekening worden verwerkt in de periode dat deze zich voordoen of waarop deze betrekking hebben" (Commissie BBV 2017, pp. 11 en 15). Voor wat betreft het bepalen van de juiste periode vervolgt de commissie: "Lasten zijn uitgaven die aan een periode zijn toegerekend. De lasten in een begrotingsjaar zijn de uitgaven die in dat jaar of in een ander jaar hebben plaatsgevonden of zullen plaatsvinden, maar die op het begrotingsjaar drukken, omdat hetzij de uitvoering van een taak die leidde tot kosten in het begrotingsjaar plaatsvond hetzij omdat het verlies in het begrotingsjaar plaatsvond" (Commissie BBV 2017, p. 17). Dit principe wordt ook wel het veroorzakingsbeginsel genoemd en kan als deelbeginsel van het realiteitsbeginsel worden aangemerkt. Het realiteitsbeginsel is één van de pijlers van goed koopmansgebruik, de geëigende manier om totaalresultaten toe te rekenen naar de diverse jaren en de manier die tevens fiscaal is voorgeschreven (Albregtse et al. 2017, p. 210).

Het komt echter voor, dat budgetten niet geheel tot besteding komen in enig jaar. Portefeuillehouders zullen in zo'n situatie doorgaans moeten uitleggen waarom de voorgenomen activiteiten niet zijn uitgevoerd (Bovens 2007; Lin et al. 1993). Managers zijn dan bevreesd dat zij het restantbudget zien terugvloeien naar de algemene middelen en dat zij in het ergste geval gekort worden op hun budgetten voor het volgende jaar (Anderson 2006; Platform Rechtmatigheid 2008). Om deze problemen op te lossen en het budget 'veilig' te stellen, wordt soms het budget overgeheveld door de lasten alsnog in het oude jaar te boeken. Dit kan door het opvoeren van een fictieve verplichting op de balans, maar uiteraard ook door de beoogde leverancier of dienstverlener te vragen zijn factuur 
vast in te sturen. In beide gevallen worden lasten geboekt in het onjuiste jaar. De prestaties zijn immers nog niet geleverd. Daarmee wordt in strijd gehandeld met het stelsel van baten en lasten, aldus de commissie (Commissie BBV 2008). Dit verschijnsel staat ook wel bekend als de decemberkoorts (Anderson 2011, p. 72). De commissie BBV stelt in dit verband: "Baten en lasten moeten worden toegerekend aan het boekjaar waarop zij betrekking hebben, dat wil zeggen dat lasten ten laste van het boekjaar mogen worden gebracht als de betreffende activiteiten ook zijn uitgevoerd. Het aangaan van een verplichting is niet voldoende om de last horend bij de verplichting in de rekening van baten en lasten en balans te verwerken. Het BBV is daar duidelijk over." (Commissie BBV 2008).

De koninklijke weg is dan, om het budget in het juiste jaar vrij te laten vallen en om de begroting voor het komende jaar aan te passen. De manager zal echter dan soms maanden moeten wachten, aangezien de begroting niet iedere week wordt gewijzigd. Ook zal de jaarrekening eerst door de gemeenteraad moeten worden vastgesteld. Pas dan vallen de middelen immers vrij. Deze vaststelling vindt meestal in mei of juni plaats, zodat ook hierdoor een vrij grote vertraging optreedt. Bovendien heeft de portefeuillehouder dan nog steeds uit te leggen waarom het budget in het oorspronkelijke jaar niet tot besteding is gekomen. Onder druk van managers gaan controllers dan soms mee met het bewust boeken van lasten in het oorspronkelijke en dus incorrecte jaar.

\section{Compliance en controllers, verklarende factoren}

De druk die managers uitoefenen op controllers om tot non-compliance over te gaan, kan zijn oorzaak vinden in het streven naar budgetmaximalisatie en kan verklaard worden vanuit de public choice-theorie (Niskanen 1971). Hoewel hiermee de aanleiding verklaard kan worden (de behoefte van managers om lasten in een verkeerd jaar te boeken), levert deze benadering nog niet een verklaring voor de mate waarin controllers toegeven aan deze druk.

Verschillende auteurs dragen verschillende verklaringen aan voor de mate van compliance. Zo wordt de bekendheid met een bepaalde regel van belang geacht. Tevens is de gepercipieerde ondoelmatigheid van een regel een factor die van belang kan zijn. Daarnaast lijkt de manier waarop de organisatie zelf het naleven van regels aanmoedigt van belang, terwijl ook de mogelijke weerstand bij managers en bestuurders zelf een relevante factor kan zijn (vgl. Gelderman et al. 2006; Burns and Scapens 2000; Pronk 2003). De weerstand bij managers wordt soms verklaard vanuit de agency-theorie (Hooghiemstra 2012). Ook kan een bepaalde afhankelijkheid bij controller van managers en bestuurders ertoe leiden dat tot non-compliance wordt overgegaan (Kaplan 2001, p. 287; Merchant and Rockness 1994, p. 90). Een andere verklaring kan liggen in de constatering door controllers dat andere or- ganisaties geen negatieve gevolgen ondervinden (Shrives and Brennan 2015). Andere auteurs onderscheiden andere factoren en hanteren andere indelingen. Zo onderscheidt Ruimschotel een drietal dimensies van compliance of naleving: de mate van overtreding op grond van gebrek aan kennis, spontane naleving en afdwongen naleving (Ruimschotel 2014, p. 147). Sommigen onderscheiden factoren naar factoren op individueel niveau, op organisatieniveau en op boven-organisatieniveau (Carpenter and Feroz 2001; vgl. Goodpaster and Matthews 1982). Ook worden wel verklaringen gezocht in het toezicht op organisaties. Informeel toezicht zou dan sneller tot compliance leiden, terwijl formeel toezicht eerder opportunisme en non-compliance in de hand werkt (Gilliland and Manning 2002). Weer anderen onderscheiden factoren gelegen buiten de organisatie, zoals maatschappelijke druk of externe controle en factoren gelegen binnen de organisatie, zoals organisatiecultuur, druk vanuit het management, financiële positie (Burns and Scapens 2000; Robalo 2014). Als men wensen van ambtelijke en bestuurlijke actoren aanmerkt als interne factoren en als men externe accountantscontrole aanmerkt als externe factor, lijkt dit onderscheid voor dit onderzoek zeer bruikbaar.

Complicerend is daarbij, dat de bovenstaande factoren weliswaar een rol kunnen spelen, maar dat het uiteindelijk om de perceptie van de controller zelf gaat. Als een bepaalde factor, zoals de detectiekans of een cultuur van compliance, aanwezig is, maar niet als zodanig door de controller wordt ingeschat, dan zal deze factor in mindere mate een rol kunnen spelen in de afweging die de controller maakt. De controller zal een inschatting maken van de voor- en nadelen van compliance, maar ook van non-compliance. Deze voor- en nadelen zijn uiteraard gerelateerd aan elkaar: de voordelen van compliance kunnen gelegen zijn in een goedkeurende accountantsverklaring, de nadelen van non-compliance kunnen gelegen zijn in het risico dat de accountant deze verklaring onthoudt. De uiteindelijke inschatting kan worden gebaseerd op een vermeend organisatiebelang, een normatieve overtuiging, maar ook beïnvloed worden door de omgeving (Flory et al. 1992, p. 287; Goodpaster and Matthews 1982; vgl. Merchant and Rockness 1994, p. 81).

Om hier enig beeld in te verkrijgen, zijn ten behoeve van dit onderzoek 14 vraaggesprekken gevoerd met controllers, die in 2017 en 2018 werkzaam waren binnen gemeentelijke organisaties. Deze vraaggesprekken hadden een verkennend karakter: centraal tijdens deze gesprekken stond de vraag welke factoren nu (vrijwel) altijd een rol spelen in de keuze van de controller om al dan niet tot compliance over te gaan. In het verlengde van de vraagstelling van dit onderzoek zijn de aangedragen factoren onderscheiden naar interne factoren (zoals bijvoorbeeld de reactie van een leidinggevende op het handelen van de controller) en externe factoren (zoals bijvoorbeeld de reactie van een accountant op het handelen van de controller).

Uit deze vraaggesprekken blijkt, dat de controller in ieder geval twee vragen probeert te beantwoorden om tot zijn afweging te komen: wat zijn de gevolgen van non-compli- 
ance voor de accountantscontrole en wat zijn de gevolgen van compliance voor zijn relatie met het management? Zo kan non-compliance leiden tot een kans op een correctie, maar ook tot een mogelijke afkeuring van de jaarstukken door de accountant. Zelfs kan dit leiden tot een negatieve reputatie van de controller, welke ook een extern effect kan hebben. Compliance kan intern tot gevolg hebben dat de controller door zijn collega's als minder empathisch wordt ervaren. Dit kan tevens functioneel doorwerken naar andere taakonderdelen van de controller en in het ergste geval leiden tot een negatieve beoordeling van de controller.

De bovengenoemde interne en externe factoren kwamen in alle vraaggesprekken naar boven. Zoals gesteld speelt de perceptie van de controller van deze factoren en zijn eigen referentiekader een rol in de afweging die de controller maakt. Het onderzoek richt zich dan ook niet alleen op de objectieve aan- of afwezigheid van deze factoren, maar tevens op de perceptie en weging van de controller van deze factoren.

Deze interne en externe factoren kunnen een inherente spanning opleveren ten opzichte van elkaar. Zo kan non-compliance tot negatieve gevolgen leiden (zoals een afkeuring van de jaarrekening), maar kan ook compliance negatieve gevolgen hebben (zoals een negatieve beoordeling). Deze spanning wordt door alle ondervraagde controllers herkend. De inventarisatie en inschatting van deze gevolgen door de controller, lijkt dan bepalend voor de mate van compliance. Deze inventarisatie en inschatting kan aangemerkt worden als de oriëntatie van de controller. Een meer interne oriëntatie (op het management) impliceert, dat de negatieve gevolgen van compliant handelen zwaarder worden ingeschat dan de negatieve gevolgen van non-compliant handelen. Een meer externe oriëntatie laat juist de balans uitslaan naar compliant handelen.

\section{Conceptualisering en operationalisering van het onderzoek}

Het onderzoek is opgezet in twee fasen. In de eerste fase wordt een kwantitatief beeld verkregen van de mate waarin een wettelijke bepaling wordt nageleefd. Hierin wordt ook de afweging betrokken die de controller maakt. Deze afweging is gebaseerd op de inschatting die de controller maakt van de gevolgen van een bepaalde mate van compliance. In de tweede fase worden in kwalitatieve zin mogelijke achterliggende verklaringen gezocht die bepalend kunnen zijn voor de mate van compliance. Conceptueel kan het onderzoek worden weergegeven met behulp van figuur 1 .

Het onderzoek richt zich dus op de mate waarin een geselecteerde wettelijke bepaling wordt nageleefd. Daarnaast brengt het onderzoek de gemaakte inschatting van de controller van de gevolgen van compliance en non-compliance in beeld. Tot slot traceert het onderzoek mogelijke achterliggende factoren.
De wettelijke bepaling, de naleving hiervan, de inschatting van de controller en de mogelijke achterliggende factoren, worden in dit onderzoek als volgt uitgewerkt.

De geselecteerde wettelijke bepaling betreft de bepaling uit artikel 2 lid 2 van het BBV, die bepaalt dat de baten en de lasten in de jaarstukken worden opgenomen, onverschillig of zij tot inkomsten of uitgaven in dat jaar leiden. Controllers worden geacht deze bepaling te kennen. Centraal in dit onderzoek staat immers de spanning die zich kan voordoen tussen de wensen van het gemeentelijk management en het naleven van wettelijke bepalingen. Noodzakelijk is dan, dat deze bepalingen bekend zijn bij de gemeentelijke controller (Ruimschotel 2014).

In dit onderzoek is eerst kwantitatief bezien in welke mate de controller de geselecteerde wettelijke bepaling naleeft. Daartoe is een basissituatie verondersteld waarin een aantal handelingsperspectieven denkbaar zijn die variëren in de mate van compliance (vgl. Merchant and Rockness 1994, p. 85; Kaplan 2001, p. 286). De basissituatie is, dat in december 2017 beschikbare budgetten nog niet zijn uitgeput en dat in het geheel nog niet met een opdrachtverstrekking en -vervulling begonnen is. Het eerste handelingsperspectief is dan, dat het restantbudget via het rekeningsaldo terugvloeit naar de algemene middelen. Dit eerste handelingsperspectief valt binnen de wettelijke bepaling. Het tweede handelingsperspectief is, dat men een overeenkomst afsluit met een potentiële opdrachtnemer en deze overeenkomst opvoert als verplichting. Men voert de verplichting op onder de passivapost "nog te betalen kosten" en daarmee verlaagt men navenant het exploitatiesaldo. Dit is toegestaan, mits sprake is van een juridisch afdwingbare verplichting (HR 7 december 1983, nr. 23 312; BNB 1984/37). Als de diensten in het geheel nog moeten beginnen, zal van een juridisch afdwingbare verplichting echter niet snel sprake zijn (Albregtse et al. 2017, p. 214). Het derde perspectief is, dat een externe partij die men op het oog heeft om een opdracht voor de gemeente uit te voeren, gevraagd wordt alvast te factureren in het lopende jaar. De factuur wordt dan geboekt ten laste van de lopende exploitatie, terwijl de daadwerkelijke opdracht pas in het volgende jaar wordt uitgevoerd. Dit is zonder meer niet toegestaan. In het vierde perspectief voert men een last op in de administratie waar in het geheel geen overeenkomst of factuur aan ten grondslag ligt. Het is evident dat ook dit handelingsperspectief niet is toegestaan. Denkbaar zou zijn geweest om meerdere situaties voor te leggen, gecombineerd met handelingsperspectieven (Flory et al. 1992). Om het onderzoek realistisch af te baken is hier echter niet voor gekozen en is uitgegaan van één basissituatie.

De afweging die de controller maakt is gebaseerd op zijn eigen inschatting van de gevolgen van compliance of juist van non-compliance.

In aansluiting op het conceptueel model, is de centrale gedachte, dat de inschatting die de controller maakt van de bovenstaande gevolgen bepalend kan zijn voor de mate van compliance. Als de controller bijvoorbeeld de 
Figuur 1. Conceptualisatie van het onderzoek.

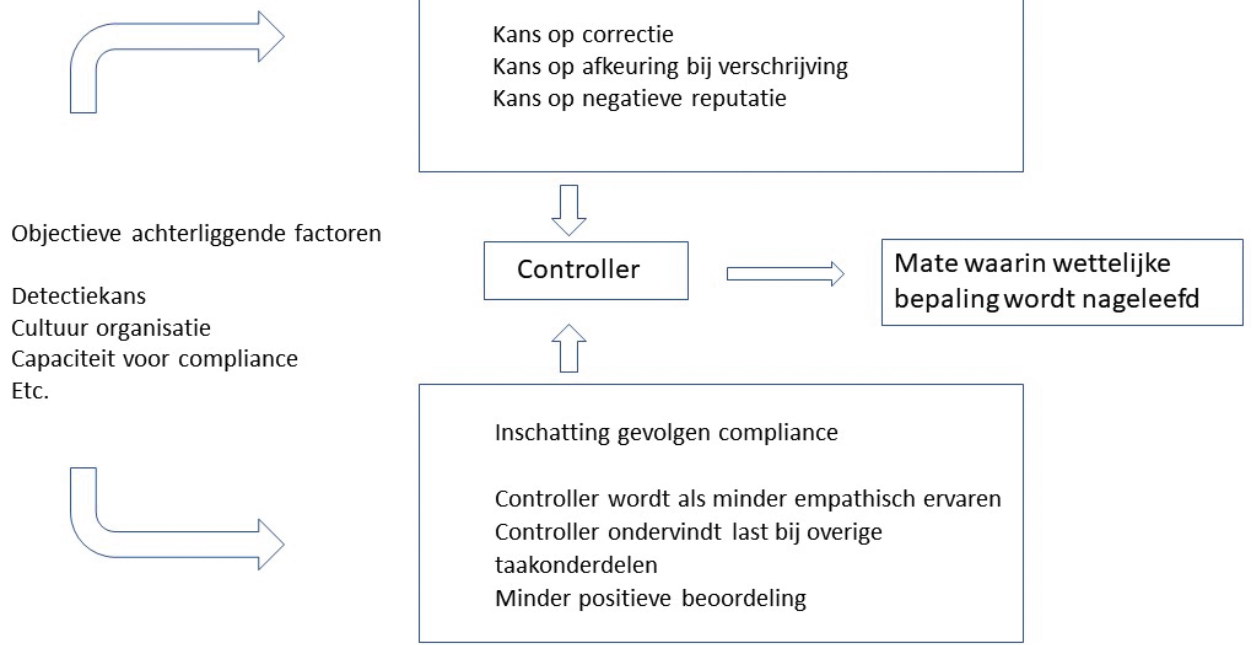

negatieve gevolgen van non-compliance gering inschat (hij maakt zich bijvoorbeeld minder zorgen om het oordeel van de accountant), zal hij sneller de neiging hebben om naast het eerste handelingsperspectief op te schuiven naar het tweede, derde of vierde handelingsperspectief. Zijn oriëntatie is dan intern. Als de controller de negatieve gevolgen van compliance gering inschat (hij maakt zich bijvoorbeeld minder zorgen om het oordeel van zijn leidinggevende of zijn collega's), zal hij eerder geneigd zijn om zich te beperken tot het eerste handelingsperspectief. Zijn oriëntatie is dan extern.

Het handelingsperspectief en de oriëntatie kunnen gecombineerd worden weergegeven (tabel 1).
De achterliggende factoren die van invloed kunnen zijn op de afweging die de controller maakt, zijn niet op voorhand te duiden, maar zijn het onderwerp van de interviews die in de kwalitatieve fase van dit onderzoek werden afgenomen.

\section{Opzet van onderzoek}

De mate waarin controllers zich aan een bepaling houden kan als een dichotome variabele gemeten worden (of je voldoet aan de regel of je voldoet niet). Het nadeel hiervan is, dat de mate van compliance achterwege blijft.

Tabel 1. Combinatie handelingsperspectief en oriëntatie.

\begin{tabular}{|c|c|c|c|}
\hline Basissituatie & Handelingsperspectief & Relatie wettelijke bepaling & Oriëntatie \\
\hline $\begin{array}{l}\text { Beschikbaar budget nog niet } \\
\text { uitgeput en er is nog geen start } \\
\text { gemaakt met de opdracht door } \\
\text { een externe partij. }\end{array}$ & $\begin{array}{l}\text { Onderuitputting wordt } \\
\text { verwerkt in rekeningresultaat } \\
\text { en eventueel nadien bestemd. } \\
\text { Begrotingswijziging wordt } \\
\text { voorgelegd met daarin de vorming } \\
\text { van een bestemmingsreserve. }\end{array}$ & Conform wettelijke bepaling. & $\begin{array}{c}\text { Extern } \\
\text { (correctie jaarrekening, } \\
\text { afkeuring jaarrekening, } \\
\text { negatieve externe reputatie) }\end{array}$ \\
\hline Idem. & $\begin{array}{l}\text { Overeenkomst wordt aangegaan } \\
\text { met opdrachtnemer en deze wordt } \\
\text { geboekt als verplichting onder } \\
\text { passiva. }\end{array}$ & $\begin{array}{l}\text { Indien sprake is van een } \\
\text { juridisch afdwingbare } \\
\text { verplichting is dit conform. } \\
\text { Anders niet conform. }\end{array}$ & Minder extern \\
\hline Idem. & $\begin{array}{l}\text { Factuur wordt vast opgestuurd } \\
\text { en geboekt onder de lasten bij de } \\
\text { lopende exploitatie. }\end{array}$ & Niet conform. & Minder intern \\
\hline Idem. & $\begin{array}{l}\text { Boeking wordt zonder factuur } \\
\text { administratief ingeboekt onder de } \\
\text { lasten bij de lopende exploitatie. }\end{array}$ & Niet conform. & $\begin{array}{c}\text { Intern } \\
\text { (collega's ervaren u als } \\
\text { minder toegankelijk, } \mathrm{u} \\
\text { ervaart hinder bij overige } \\
\text { werkzaamheden, er ontstaat } \\
\text { een kans op een negatieve } \\
\text { beoordeling) }\end{array}$ \\
\hline
\end{tabular}


Ook kunnen controllers een aantal situaties worden voorgelegd, waar de controllers daadwerkelijk mee geconfronteerd worden in hun praktijk, met het verzoek deze te voorzien van een "ethische score" (Bruns and Merchant 1989; Flory et al. 1992). Een groot knelpunt kan dan de betrouwbaarheid van de respons zijn: controllers zullen immers niet snel vrijelijk toegeven dat hun mate van compliance beperkt is. Dit probleem kan deels verholpen worden door het onderzoek niet zozeer te richten op de daadwerkelijke non-compliance van de controller, maar de controller een aantal hypothetische situaties en handelingen voor te leggen met het verzoek deze te voorzien van een ethische score (vgl. Merchant and Rockness 1994; Kaplan 2001; Flory et al. 1992). Het onderzoek wordt dan feitelijk weggeleid van de praktijk waarin de controller zich bevindt (vgl. Gelderman et al. 2006). Het nadeel daarvan is dan ook, dat de beoordeling van een hypothetische situatie door de controller niet zonder meer kan worden doorgetrokken naar eenzelfde beoordeling en naar hetzelfde handelen in een daadwerkelijke situatie (Flory et al. 1992, p. 295). Feitelijk bevindt zich hier een spanning: naarmate het onderzoek zich sterker richt op het daadwerkelijke handelen van de controller, zal de controller zelf een minder betrouwbare respondent zijn.

De vraag blijft dan, in hoeverre controllers een betrouwbaar beeld geven van hun eigen handelen. Om dit probleem te verhelpen wordt ten behoeve van dit onderzoek aangesloten op een methode die in integriteitsonderzoek veelvuldig wordt gebruikt. Men voert dan juist niet de controller, maar nauw betrokkenen op als respondent. In eerder onderzoek worden deze betrokkenen dan hypothetische situaties voorgelegd met het verzoek stelling te nemen ten aanzien van deze situaties (vgl. Merchant and Rockness 1994, p. 85; Flory et al. 1992, p. 295). Het nadeel hiervan is echter, dat ook hiermee het onderzoek wordt weggeleid van de praktijk en men een minder nauwkeurig beeld krijgt van de mate waarin gemeentelijke controllers in de praktijk nu daadwerkelijk compliant zijn.

Daarom is in dit onderzoek een aantal betrokkenen gevraagd om aan te geven welk handelingsperspectief hun eigen controller daadwerkelijk toepast indien de basissituatie zich voordoet (vgl. De Graaf and Strüwer 2014). Op deze manier wordt een beeld gekregen van de manier waarop controllers met de specifieke bepaling in de praktijk omgaan. Uiteraard zal zich hier een zekere vertekening voordoen. Naarmate de betrokkenen een goede verstandhouding met de controller hebben, zal de kans groter worden dat zij de controller wat meer 'compliant' beschrijven (Kaplan 2001, p. 288; Singer and Singer 1997, p. 474). Aan de andere kant rijst de vraag in hoeverre de betrokkenen altijd een goede verstandhouding met de controller hebben (Kaplan 2001, p. 295).

In deze fase is gebruik gemaakt van een enquête die onder 66 betrokkenen is uitgezet. Deze 66 betrokkenen kunnen gerelateerd worden aan 22 controllers; drie betrokkenen per controller: het gaat in alle gevallen om financieel administratief medewerkers, assistent controllers of medewerkers van het team van de controller.
Noodzakelijk is daarbij dat deze betrokkenen een goed zicht hebben op de financiële aanwijzingen van de controller en ook zicht hebben op de uiteindelijke boekingen. Noodzakelijk is tevens, dat de gemeentecontrollers zelf niet alleen toegang hebben tot de financiële administratie, maar ook aanwijzingen kunnen geven met betrekking tot deze administratie. Uiteraard moet de basissituatie zich daadwerkelijk hebben voorgedaan. De enquête is in eerste instantie uitgezet onder 215 betrokkenen. In sommige situaties bleek echter de controller niet over de bevoegdheid te beschikken om aanwijzingen te geven met betrekking tot de financiële administratie of bleek geen sprake te zijn van onderuitputting. Uiteindelijk bleven 66 betrokkenen over die gerelateerd kunnen worden aan 22 controllers die wel over de bevoegdheid beschikken om aanwijzingen te geven en waarbij tevens sprake was van onderuitputting. Al deze 66 betrokkenen is dezelfde basissituatie voorgelegd, met de vier mogelijke handelingsperspectieven. Deze betrokkenen konden vervolgens aangeven of hun controller in 2017 daadwerkelijk gebruik had gemaakt van één van de vier handelingsperspectieven (dit konden er ook meerdere zijn).

Om een kwantitatief beeld te krijgen van de afweging die de controller maakt, moet uiteraard juist wel de controller zelf benaderd worden. Deze afweging kon inzichtelijk worden gemaakt, door de 22 controllers de zes eerder opgevoerde gevolgen van compliance en non-compliance voor te leggen. Vervolgens konden deze controllers een gewicht toekennen aan deze gevolgen (vgl. Gelderman et al. 2006; Flory et al. 1992, p. 289).

Zo ontstaat een kwantitatief beeld van de mate waarin een controller compliant handelt, terwijl tevens een beeld ontstaat van de inschatting door deze controller van de gevolgen van een bepaald handelingsperspectief. Deze twee beelden zijn onafhankelijk van elkaar tot stand gekomen.

Vervolgens zijn aan de hand van 12 vraaggesprekken in kwalitatieve zin achterliggende verklaringen gezocht voor de manier waarop gemeentecontrollers met deze bepalingen omgaan (vgl. Bertz and Quinn 2014; Robalo 2014). Deze verklaringen kunnen zeer verschillend zijn (Stevens 2007; Bertz and Quinn 2014). Tijdens deze gesprekken zijn de vragen zo open mogelijk geformuleerd om op voorhand geen inzichten en verklaringen uit te sluiten.

\section{Analyse resultaten}

Op de vraag welk handelingsperspectief door de controller wordt aangewend, wordt door de betrokkenen verschillend geantwoord, maar per controller verschillen de betrokkenen minder. Bij zeven van de 22 controllers wordt geconstateerd, dat gebruik wordt gemaakt van een boeking zonder factuur of verplichting. Dertien controllers verzoeken de leverancier alvast de factuur op te sturen. Veertien controllers boeken de overeenkomst als verplichting in.

In de steekproef wordt een verschil in score tussen intern en extern georiënteerde controllers geconstateerd, waarbij vastgesteld kan worden dat de groep van intern 
georiënteerde controllers sneller geneigd is om over te gaan op handelingsperspectief 2, 3 of zelfs 4 . Het verschil tussen beide groepen is significant. Ook als enkel het hoogste handelingsperspectief wordt geteld, is het verband sterk (de Spearman's waarde bedraagt 0.756).

Vanuit het geconstateerde verband tussen de afweging die de controller maakt en het handelingsperspectief dat de controller aanwendt, zijn vervolgens 12 interviews afgenomen. De respondenten betroffen de controllers uit de steekproef. Bewust is ervoor gekozen zes controllers met een interne en zes controllers met een externe oriëntatie te selecteren, om een zo volledig mogelijk beeld te krijgen.

Alle controllers geven aan geconfronteerd te worden met onderuitputtingen. In de meeste gevallen wordt dan druk ervaren van het management of de betreffende portefeuillehouder om deze onderuitputtingen veilig te stellen op een andere manier dan wettelijk is voorgeschreven. De reden hiervoor is, dat het vaststellen van de jaarrekening vaak pas plaatsvindt in mei of juni van het volgend jaar en dat eerdere beschikbaarheid van het budget gewenst is. Bovendien heeft men bij onderuitputting vaak wat uit te leggen richting de gemeenteraad. De portefeuillehouder zal dan immers moeten aangeven waarom de budgetten niet tot besteding zijn gekomen. Alle controllers zijn bekend met de wettelijke bepalingen en met de stellingname van hun accountant: de controllers zijn zich ervan bewust dat de handelingsperspectieven 2 tot en met 4 kunnen leiden tot een reactie van de accountant. De negatieve gevolgen van non-compliant gedrag worden door de ondervraagde controllers in gelijke mate erkend en ook een gelijk gewicht toegekend. De negatieve gevolgen van compliant gedrag worden echter verschillend ingeschat. De intern georiënteerde controllers schatten deze gevolgen zwaar in, de extern georiënteerde controllers erkennen deze gevolgen in mindere mate en als zij dat al doen, dan worden deze gevolgen door de extern georiënteerde controllers minder zwaar ingeschat.

De kwalitatieve analyse levert verder op, dat een verband bestaat tussen de positionering van de controller en zijn oriëntatie. Opvallend is namelijk, dat vijf van de zes intern georiënteerde controllers hiërarchisch decentraal gepositioneerd zijn. Deze vijf controllers werken binnen een sector of directie en worden beoordeeld door een directeur, niet zijnde de algemeen directeur. Het gaat dan om vakinhoudelijke sectoren of directies op het gebied van het sociaal domein, grondexploitatie, ruimtelijk beheer, etc. Slechts één van de intern georiënteerde controllers is werkzaam binnen de directie Middelen. Geen verband is geconstateerd tussen de vakinhoudelijke sectoren waarbinnen de controller werkzaam is en de mate van compliance of de afweging die hij maakt. Controllers die werkzaam zijn binnen een sector ruimtelijk beheer, maken bijvoorbeeld dezelfde afweging en zijn in dezelfde mate compliant als controllers die werkzaam zijn binnen een sector sociaal domein. De zes extern georiënteerde controllers zijn in alle gevallen gepositioneerd binnen de directie Middelen, of vallen hiërarchisch onder de concerncontroller of zelfs de algemeen directeur (de gemeentesecretaris).
Dat men druk ervaart wil niet zeggen dat de negatieve gevolgen die men inschat, zich daadwerkelijk voordoen. Van de zes intern georiënteerde controllers geeft slechts één controller aan dat de manager daadwerkelijk tot een minder positieve beoordeling overging in een geval van compliance (en dat betrof overigens niet de geïnterviewde controller zelf). Twee intern georiënteerde controllers geven aan in de praktijk negatieve gevolgen op andere terreinen te hebben ervaren bij al te compliant gedrag. $\mathrm{Zij}$ ondervonden tegenwerking bij andere voorstellen of planning \& control-producties. Eén intern georiënteerde controller werd als minder toegankelijk ervaren door zijn collega's, vanwege het feit dat hij als "strak in de leer" werd ervaren. De extern georiënteerde controllers kunnen geen voorbeelden noemen van negatieve gevolgen van compliant gedrag die zich daadwerkelijk hebben voorgedaan in de praktijk. Van de negatieve consequenties van non-compliant handelen weten alle 12 controllers voorbeelden te noemen. De meest voorkomende is een correctie van de jaarrekening.

Geen van de ondervraagde controllers heeft ooit vanuit zijn manager of portefeuillehouder instructies gekregen om minder compliant te handelen. Wel wordt de controller verzocht op zoek te gaan naar een "creatieve oplossing”. Een dergelijk verzoek om bij onderuitputting op zoek te gaan naar een creatieve oplossing is in 2017 aan iedere ondervraagde controller gedaan. In alle gevallen vormt het verzoek van een manager of portefeuillehouder de aanleiding om op zoek te gaan naar andere handelingsperspectieven. De controller wacht dus dit verzoek af, dat overigens ook soms impliciet wordt gedaan. Nadat dit verzoek is gedaan, gaat de intern georiënteerde controller doorgaans op zoek naar mogelijkheden. De handelingsperspectieven uit dit onderzoek dekken deze mogelijkheden goed af: andere perspectieven verschillen niet wezenlijk van de vier perspectieven die zijn onderzocht en zijn daar goed binnen te plaatsen. De extern georiënteerde controller wijst dit verzoek doorgaans af. Deze controller beroept zich dan op het argument dat de accountant niet gecharmeerd is van een creatief handelingsperspectief.

$\mathrm{Bij}$ het opteren voor handelingsperspectief 2 tot en met 4 zoekt de controller doorgaans samenwerking met budgethouders en zorgt de controller eveneens voor rugdekking van zijn leidinggevende (doorgaans een directeur). In alle gevallen stelt hij de budgethouders en de leidinggevende op de hoogte van zijn geopteerde werkwijze. Dit verhoogt de medeplichtigheid en versterkt de rugdekking, mocht een en ander niet goed verlopen, aldus de respons in dit verband. In sommige gevallen laat de controller de actieve handeling aan de budgethouder over: deze boekt dan de verplichting in, laat de factuur vast opsturen of biedt een stuk aan ter inboeking. Op deze manier wordt een en ander buiten het zicht van de financiële administratie en van het werkveld van de controller zelf gehouden, zo wordt gesteld. Dit impliceert, dat het zicht van de direct betrokkenen, die immers veelal in de afdeling of het team van de controller werkzaam zijn, beperkt is en dat mogelijkerwijs nog vaker van de handelingsperspec- 
tieven 2 tot en met 4 gebruik wordt gemaakt. Bij het opteren voor handelingsperspectief 1 wordt soms de algemeen directeur of de concerncontroller in stelling gebracht om de slechte boodschap te brengen.

Het handelingsperspectief wordt mede bepaald door de aard van de dienst. Zo biedt het uitbesteden van een onderzoek meer mogelijkheden voor verschillende handelingsperspectieven dan de aanbesteding op het gebied van openbare werken of aanbestedingen binnen het sociaal domein. Ingehuurde capaciteit (zoals het gebruik van uitzendkrachten) levert eveneens weinig mogelijkheden op voor al te creatieve handelingsperspectieven. Het gegeven dat verschillende handelingsperspectieven mogelijk zijn, vormt niet de directe aanleiding om daadwerkelijk tot een creatiever handelingsperspectief over te gaan. De directe aanleiding is de druk die de controller ervaart vanuit zijn directeur of zijn portefeuillehouder. Vervolgens wordt dan naar een mogelijkheid gezocht. De controller gaat dan bewust na of sprake is van ingehuurde diensten die zich lenen voor creatievere handelingsperspectieven.

\section{Conclusies}

Gemeentecontrollers kunnen geconfronteerd worden met enerzijds de bepalingen die het BBV voorschrijft, en anderzijds de behoeften van het management om budgetten veilig te stellen.

In dit onderzoek staat de vraag centraal in welke mate gemeentecontrollers de wettelijke bepalingen naleven, zoals deze zijn geformuleerd in het BBV en welke factoren deze mate kunnen verklaren. Hiertoe is één wettelijke bepaling geselecteerd (artikel 2 lid 2 van het BBV, dat bepaalt dat de baten en de lasten in de jaarstukken worden opgenomen, onverschillig of zij tot inkomsten of uitgaven in dat jaar leiden). Bij 22 gemeentecontrollers is onderzocht in hoeverre deze bepaling wordt nageleefd. Vervolgens is bezien welke afwegingen de controller maakt met betrekking tot deze bepaling en welke inschatting hij maakt van de gevolgen die het naleven of juist het niet naleven opleveren. Tot slot zijn achterliggende factoren getraceerd die van invloed kunnen zijn op deze afweging.

Veertien controllers opteren voor handelingsperspectieven die zich minder goed verhouden tot de wettelijke bepaling. In zeven gevallen wordt gebruik gemaakt van een boeking zonder factuur of verplichting. Dertien controllers verzoeken de leverancier alvast een factuur op te sturen, terwijl de prestatie pas het volgend jaar plaatsvindt.

De controller maakt een afweging die gebaseerd is op zijn inschatting van de negatieve gevolgen van non-compliant handelen versus de negatieve gevolgen van compliant handelen. Zo kan non-compliant handelen leiden tot een correctie van de accountant, een afkeuring van de jaarrekening of zelfs een negatieve externe reputatie.
Compliant handelen kan leiden tot antipathie bij collega's, tegenwerking op andere terreinen en zelfs tot een minder positieve beoordeling.

Controllers die intern zijn georiënteerd, maken vaker gebruik van handelingsperspectieven die zich minder goed verhouden tot het doel, de strekking of zelfs de letterlijke tekst van het BBV. Te denken valt dan aan het aangaan van een overeenkomst en deze inboeken als verplichting, terwijl in het geheel nog geen werkzaamheden zijn uitgevoerd. Ook komt het voor dat de opdrachtnemer wordt verzocht een factuur op te sturen, die dan vervolgens wordt geboekt in het betreffende jaar, terwijl de daadwerkelijke prestatie pas geleverd wordt in het daaropvolgende jaar. In sommige gevallen wordt zelfs zonder onderliggende factuur of overeenkomst een boeking ingevoerd.

De vraag waarom sommige controllers intern en andere controllers extern zijn georiënteerd, is in dit onderzoek kwalitatief aan de orde gesteld. Een decentrale positionering van de controller, waarbij de controller werkzaam is binnen een vakinhoudelijke sector (niet zijnde de sector Middelen), werkt een interne oriëntatie in de hand. Deze controllers worden beoordeeld door een vakinhoudelijke directeur. Een centrale positionering, waarbij de controller werkzaam is op concernniveau of binnen een sector Middelen, bevordert een externe oriëntatie. Deze controllers worden beoordeeld door de directeur Middelen, de concerncontroller of de gemeentesecretaris. Dit verband is ook in kwantitatieve zin significant.

Het feit dat de controllers druk ervaren wil niet zeggen dat de negatieve gevolgen die men inschat, zich daadwerkelijk voordoen. Aan de andere kant wordt de controller wel verzocht op zoek te gaan naar een "creatieve oplossing". Een dergelijk verzoek om bij onderuitputting op zoek te gaan naar een creatieve oplossing is in 2017 aan iedere ondervraagde controller gedaan, zij het soms impliciet.

Bij minder compliant handelen wordt veelal samenwerking met budgethouders gezocht en voorziet men tevens in rugdekking van de leidinggevende. In alle gevallen worden de budgethouders en de leidinggevende op de hoogte gesteld om op die manier de medeplichtigheid en de rugdekking te versterken.

Een associatie met de rol die de gemeentecontroller vervult ligt welhaast voor de hand. Hoewel de oriëntatie onderscheiden moet worden van de rol die de gemeentecontroller vervult, kan immers een zekere relatie worden verondersteld. Een controller die zich opstelt als adviseur van het management, zal eerder intern zijn georiënteerd dan een controller die zich als toezichthouder of controleur opstelt. Hier kan nader onderzoek ons inzicht vergroten. Als er inderdaad een relatie bestaat tussen de oriëntatie en de rolvervulling van de gemeentecontroller, rijst immers de vraag in hoeverre de gearticuleerde wens om de controller te positioneren als adviseur van het management niet genuanceerd moet worden.

Dr. Rick Anderson is als onderzoeker verbonden aan EIFFEL. 


\section{Literatuur}

- Aardema H (2000) Contextmanagement, een nieuw bestuurs- en managementconcept. VNG-uitgeverij (Den Haag).

- Aardema H (2007) Control voor leiders. Elsevier Overheid (Den Haag).

- Albregtse D, Arends A, Essers P (2017) Belastingrecht Inkomstenbelasting. Wolters Kluwer (Deventer).

- Anderson RJ (2006) Tussen schakelen en switchen, over de rol van de controller in gemeentelijke organisaties. Gildeprint (Enschede).

- Anderson RJ (2011) In control of uit de hand. Kluwer (Deventer).

- Behn R (2001) Rethinking democratic accountability. Brookings Institution Press. (Washington, DC).

- Bertz J, Quinn M (2014) Interpreting management accounting rules: an initial study of public bodies. Journal of Management Control 24(4): 319-342. https://doi.org/10.1007/s00187-014-0185-7

- Bordewijk P, Klaassen H (2011) Begroten met beleid. Pleidooi voor planning en control op maat bij de gemeenten. Sdu Uitgevers (Den Haag).

- Bovens M (2007) Analysing and assessing public accountability: A conceptual framework. European Law Journal 13(4): 447-468. https://doi.org/10.1111/j.1468-0386.2007.00378.x

- Bruns WJ, Merchant KA (1989) Ethics test for everyday managers Harvard Business Review 67(2, March/April): 220-221.

- Burns J, Scapens R (2000) Conceptualizing management accounting change: An institutional framework Management Accounting Research 11(1): 3-25. https://doi.org/10.1006/mare.1999.0119

- Carpenter V, Feroz E (2001) Institutional theory and accounting rule choice: an analysis of four US state governments' decisions to adopt generally accepted accounting principles. Accounting, Organizations and Society 26(7-8): 565-596. https://doi.org/10.1016/S03613682(00)00038-6

- Commissie BBV (2017) Raamwerk BBV: het stelsel van baten en lasten. Den Haag. https://www.commissiebbv.nl/file/download/57979924/Raamwerk\%20BBV\%20-\%20 ${ }^{\text {st }}$ elsel $\% 20$ van $\% 20$ baten\%20en\%20lasten.pdf

- De Graaf G, Strüwer T (2014) Aard en omvang van integriteitsschendingen binnen de Nederlandse overheid. BIOS, Vrije Universiteit (Amsterdam).

- Fenger M (2001) Sturing van samenwerking, Institutionele veranderingen in het beleid voor werk en inkomen. Thela Thesis, Rozenberg Publishers (Amsterdam).

- Flory SM, Phillips TJ, Reidenbach RE, Robin DP (1992) A multidimensional analysis of selected ethical issues in accounting. The Accounting Review 67(2): 284-302.

- Gelderman C, Ghijsen P, Brugman M (2006) Public procurement and $\mathrm{EU}$ tendering directives - explaining non-compliance. International Journal of Public Sector Management 19(7): 702-714. https:// doi.org/10.1108/09513550610704716

- Gilliland D, Manning K (2002) When do firms conform to regulatory control? The effect of control processes on compliance and opportunism. Journal of Public Policy \& Marketing 21(2): 319-331. https://doi.org/10.1509/jppm.21.2.319.17578

- Goodpaster KE, Matthews JB (1982) Can a corporation have a conscience? Harvard Business Review 60(1): 132-141.

- Hertogh M, Weyers H (2011) Recht van onderop. Ars Aequi Libri (Nijmegen).
- Hooghiemstra R (2012) What determines the informativeness of firms' explanations for deviations from the Dutch corporate governance code? Accounting and Business Research 42(1): 1-27. https:// doi.org/10.1080/00014788.2011.600630

- Huls N (2015) Actie en reactie. Boom Juridische uitgevers (Den Haag).

- Jansen E (2008) Bestuurlijke informatieverzorging onmisbaar voor de public controller. In Gradus RHJM, Minderman GD, Budding T, Van Egten CA (Red.) De waarde van de public controller. Sdu Uitgevers (Den Haag).

- Kaplan S (2001) Ethically related judgments by observers of earnings management. Journal of Business Ethics 32(4): 285-298. https://doi.org/10.1023/A:1010600802029

- Kidwell L (1999) Compliance reporting decisions in municipal audits: The impact of budget variance and employment sector. Journal of Public Budgeting, Accounting \& Financial Management 11(3): 325-356. https://doi.org/10.1108/JPBAFM-11-03-1999-B001

- Lin ZJ, Baxter GC, Murphy GJ (1993) Improving government financial reporting in Canada. Financial Accountability \& Management, 9(4): 235-254. https://doi.org/10.1111/j.1468-0408.1993.tb00376.x

- Mangia G, Iacono MP, Canonico P, Martinez M, Mercurio R (2013) The human side of organizational change: Compliance and management control systems in Italian public utilities. Human Factors and Ergonomics in Manufacturing \& Service Industries 23(1): 47-57. https://doi.org/10.1002/hfm.20515

- Merchant KA, Rockness J (1994) The ethics of managing earnings: An empirical investigation. Journal of Accounting and Public Policy 13(1): 79-94. https://doi.org/10.1016/0278-4254(94)90013-2

- Niskanen Jr WA (1971) Bureaucracy and representative government. Transaction Publishers / Routledge (New York).

- Otley D (1994) Management control in contemporary organizations: towards a wider framework. Management Accounting Research 5(3-4): 289-299. https://doi.org/10.1006/mare.1994.1018

- Platform Rechtmatigheid provincies en gemeenten in samenwerking met de commissie BBV (2008) Notitie budgetoverheveling tussen begrotingsjaren en rechtmatigheid. (Den Haag). https://www.commissiebbv.nl/cms/view/57979491/resultaat-bestemmen

- Price A, Schwartz R, Cohen J, Scott F, Manson H (2016) Pursuing performance and maintaining compliance: Balancing performance improvement and accountability in Ontario's public health system. Canadian Public Administration 59(2): 245-266. https://doi. org/10.1111/capa.12151

- Pronk P (2003) Indicatoren voor naleving van fiscale regelgeving door ondernemingen. Weekblad voor Fiscaal Recht 132(6518): 332-341.

- Robalo R (2014) Explanations for the gap between management accounting rules and routines: An institutional approach. Revista de Contabilidad 17(1): 88-97. https://doi.org/10.1016/j.rcsar.2014.03.002

- Ruimschotel D (2014) Goed toezicht. Mediawerf Uitgevers (Amsterdam).

- Shrives PJ, Brennan NM (2015) A typology for exploring the quality of explanations for non-compliance with UK corporate governance regulations. The British Accounting Review 47(1): 85-99. https:// doi.org/10.1016/j.bar.2014.08.002

- Singer MS, Singer AE (1997) Observer judgments about moral agents' ethical decisions: The role of scope of justice and moral intensity. Journal of Business Ethics 16: 473-484. https://doi. org/10.1023/A:1017992805903 
- Stevens L (2007) Durf te vertrouwen op open normen. Weekblad voor Fiscaal Recht 136(6736): 1090-1101.

- Strikwerda H (2002) De rol van de controller: Kerncompetent of universele adviseur?, ControllersMagazine 17(juni/juli).
- Van Helden GJ (1998) De controller van de toekomst. Tijdschrift Financieel Management 18(6): 14-22.

- Vosselman EGJ (2005) Redevoering over de overheidscontroller van de toekomst. TCG Congres, Amersfoort, mei 2005. 